ZESZYTY NAUKOWE UNIWERSYTETU SZCZECIŃSKIEGO

NR 884

EKONOMICZNE PROBLEMY USŁUG NR 119

2015

DOI: 10.18276/epu.2015.119-01

\title{
Izabela Kotowska*
}

\author{
THE INFLUENCE OF SULPHUR DIRECTIVE \\ ON THE FERRY MARKET. ŚWINOUJŚCIE-YSTAD/ \\ TRELLEBORG FERRY LINES - A CASE STUDY
}

\begin{abstract}
Transport is a sector of economy that largely contributes to the growth of global pollution. A vast majority of harmful substances emitted as a result of transport activities comes from the road transport means. However, maritime transport, due to high sulphur level in the maritime fuel oil, is mainly responsible for the emission of sulphur oxides.

In January 2015 European Union implemented Directive 2012/33/EU requiring a cut in sulphur emissions from vessels, by using low sulphur fuels or installing scrubbers on ships. The implementation of Sulphur Directive has led to an increase in shipowners operating costs and can cause a reduction in sea traffic. The study aims to show how the implementation of the new requirements of the sulphur content in maritime fuel oil in SECA has affected the activities of ferry companies. The research has been based on an analysis of the traffic and freight costs of ferry shipping market in the first half of 2015. The article presents the results of the case study of Świnoujście-Ystad/Trelleborg ferry routes. It demonstrates that the restrictions of sulphur content in maritime fuel oil neither result in a reduction of traffic, nor necessitate reorganization of transport chains.
\end{abstract}

Keywords: Sulphur Directive, Annex VI of MARPOL, sustainable transport, maritime transport

* Izabela Kotowska, Associate Prof., PhD, Maritime University of Szczecin, Faculty of Economics and Transport Engeenering, e-mail address: i.kotowska@am.szczecin.pl. 


\section{Introduction}

Sustainable transport, as one of the objectives of sustainable development, should contribute to social development and economic growth with the least negative impact on the environment. It is hard to overestimate the economic role of transport, but, unfortunately, transportation also generates negative social and environmental effects, known as externalities. Transport externalities are mainly due to the environmental pollution arising from the combustion of fossil fuels by means of transport. The main compound emitted by transport activities is carbon dioxide - a greenhouse gas that causes global warming. This entails a growing number of locally occurring floods, hurricanes, droughts and rising water levels. Apart from carbon dioxide, the burning of fossil fuels results in the formation of other pollutants such as nitrogen oxides, sulfur oxides, or particulate matters and non-methane volatile organic compounds. In Europe, transport is responsible for almost half of emissions of nitrogen oxides and about $10-15 \%$ of other pollutants and greenhouse gases.

The vast majority of harmful substances emitted as a result of transport activity come from road transport vehicles, while maritime transport, mainly due to its capacity, is considered the most environmentally friendly transport mode. However, the emissions from the maritime transport sector cannot be considered a negligible source of atmospheric pollutants in European coastal areas (Viana et. al. 2014). Maritime transport is a heavy contributor to SOx emissions due to the nature of fuel used by ship engines; that is, mainly heavy fuel oil (HFO) with a high sulphur content (Dore 2006, Doudnikoff, Lacoste 2014). Sulphur oxides are responsible for the formation of acid rain, which results in the acidification of soil. They also have a strong impact on human health and life, resulting in pulmonary and cardiovascular diseases and cancers (Pawłowska 2000). The share of maritime transport in SOx emissions is significant. The de Meyer et. al. (2008) research has demonstrated that in 2003 maritime transport was responsible for about $30 \%$ of the total emission in the Belgian part of the North Sea. Hongisto (2014) studies has shown that ship emissions contributed from $10 \%$ to $25 \%$ of the $\mathrm{SO} 2$ and $\mathrm{SO} 4$ concentrations along Baltic Sea coasts. The growing importance of $\mathrm{SO} 2$ emissions from international shipping contrasts with the strong downward trend in land-based SO2 emissions. The permissible sulphur content in the road fuel is only $10 \mathrm{ppm}$ ( 1 thou. times less than in maritime fuel oil IFO 380 $1.0 \% \mathrm{~S})$. 


\section{Annex VI of MARPOL Convention}

In response to the growing contamination resulting from maritime transport, the International Maritime Organisation introduced Annex VI to International Convention for the Prevention of Pollution from Ships (MARPOL). Although the annex was announced in 1997, it entered into force only in 2005. Annex VI limited the main air pollutants contained in ships exhaust gas, including sulphur oxides (SOx) and nitrous oxides (NOx). The annex set the global limits of sulphur in maritime fuel to $4.5 \%$ by weight. It also introduced the special SOx Emission Control Areas (SECA) covering the Baltic Sea, the North Sea and the English Channel only, where the sulphur content established not to exceed $1.5 \%$. The regulations allowed to use scrubbers instead of low sulphur fuel. This annex was implemented to European legislation by the 2005/33/EC Directive. The Directive specified the terms of introduction of the sulphur content restrictions in SECA as August 2006 at the Baltic Sea and August 2007 at the North Sea and English Canal. Additionally, since 2010 the Directive has required the use $0.1 \%$ sulphur fuel oil by ships berthing in EU ports. This restriction brought tangible benefits in short time. The research conducted in Mediterranean ports has shown that the introduction of the directive requiring all ships at berth or anchorage in European harbours to use low sulphur fuels led to decrease of the sulphur dioxide concentrations up to $66 \%$ (Schembari et. al. 2012).

Annex VI of MARPOL Convention was revised in 2008 (entered into force in 2010). It introduced new limits of the sulphur content in the maritime fuel oil up to $3.50 \%$ by weight after 1 January 2012 and $0.50 \%$ - after 1 January 2020 . Within an SECA, the sulphur content in fuel oil was set: $1 \%$ after 1 July 2010, and $0.1 \%$ after 1 January 2015 (IMO 2008). The revised Annex VI was implemented to the EU legislation by the 2012/33/EU Directive. Unfortunately, these strict regulations concern only vessels operating in SECAs, excluding the area of the Mediterranean, the Bay of Biscay and the Norwegian Sea (Fig. 1).

The adverse effect of the implementation of the Directive is the increase of the operating costs of shipowners active in SECA (Bengtsson et al. 2014). The three main options to reduce sulphur emissions: low sulphur distillates, liquefied natural gas (LNG) and, SOx scrubbers highly increase the operating costs of shipping companies (Gilbert 2014). Low sulphur distillates are about 50\% more expensive than heavy fuel oils. Using LNG as a fuel or scrubbers needs heavy investments. For example, the cost of installing a scrubber reaches $\$ 5$ million. 
The Interferry shipping association studies has shown that in 2011 of 108 examined Baltic ferries, up to 60 percent were not suitable, either for technical reasons or due to the lack of financial viability, to install scrubbers (Shipowners under Pressure of Ecology 2012).

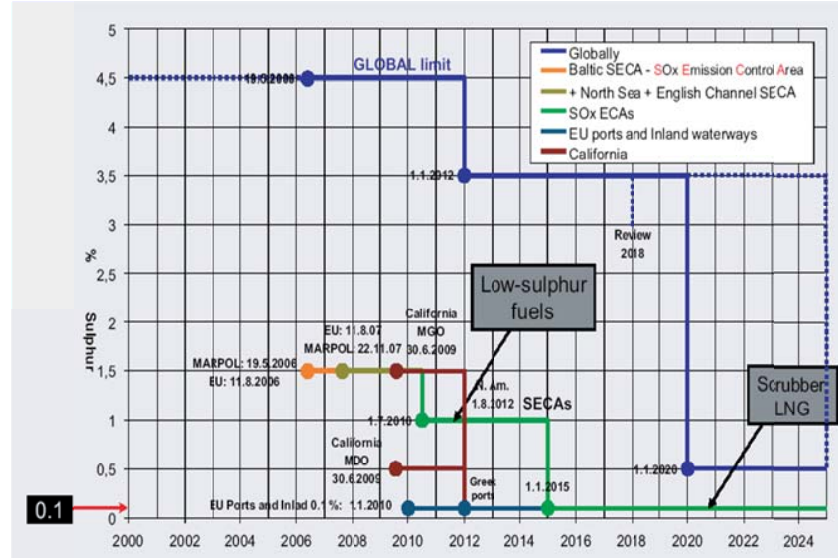

Figure 1. Sulphur emission restrictions

Source: www.publications.parliament.uk/pa/cm201012/cmselect/cmtran/1561/1561vw10.htm.

There is a concern that the increased shipping costs can lead to the reduction in maritime traffic and modal shift to road transport, effectively increasing the total adverse environmental impact. However, researchers' opinions on this issue are divided. Notteboom, Delhay and Vanherle (2010) indicate that the use of MGO $(0.1 \%)$ will have a negative effect on freight rates and the modal split on a large set of origin-destination relations. On some trade routes the short sea option might lose its appeal to customers.

Kehoe et. al. (2010) studies predicts that introduction of low sulphur fuel in SECA will cause a modal shift in favor of the road-only route by an approximate $10 \%$, while the designation of the Mediterranean as a SECA can cause a modal shift by $5.2 \%$ (Panagakos et. al. 2014).

However, not all studies support the modal shift thesis. The research results based on an analysis of five land-sea routes between Lithuania and Great Britain indicate that, despite the cost increase as a consequence of the new requirements 
for maritime fuel, a modal shift from sea-dominated routes to road-dominated routes is unlikely to occur (Holgman et. al. 2014).

\section{The economical impact of Sulphur Directive on ferry traffic}

After introducing the Sulphur Directive at the beginning of 2015, the ferry shipping found themselves in a difficult situation. The latest sulphur regulations in SECA have compelled the ferry companies to change their investment policies. Some operators, like DFDS and Color Line, have decided to install scrubbers, others, e.g. Containerships, ordered new LNG-fuelled vessels or, like Stena Line, converted the old one to methanol propulsion (Martin 2013; Roueche 2013; Bonney 2014; the Stena Line introduces methanol-fuelled ship, 2014). Unfortunately, some carriers (e.g. DFDS and Transfennica), because of the concerns that the new regulation would result in a loss of volumes, have cut some services (Brett 2015). However, most of the shipping companies began to use low sulphur fuels. All of the mentioned methods contribute to an increase in the operating costs of ferry companies, which, in turn, affects freight prices.

The article presents the impact of the cost increase caused by the introduction of sulfur directive on ferry traffic on Świnoujście-Ystad/Trelleborg routes. In order to determine the direct impact of the regulations introduced in January 2015 in SECA on the ferry market, a comparative analysis of ferry transport costs and traffic has been made. The analysis is based on the tariffs published in 2014 and 2015 by the ferry companies: Unity Line, TT Line and Polferries. The analysis of ferry traffic is based on operator statistics in 2014 and the early 2015. The 2005-2013 Shippax statistic complements the considerations.

The majority of ferry tariffs consist of three components: basic fee, bunker adjustment factor surcharge (BAF) and low sulphur surcharge (LS). Two out of the three analyzed tariffs of ferry carriers operating on the analyzed lines are designed in this way. In both cases the basic fee did not change in 2015, but the low sulphur surcharge has increased. Despite a significant decrease of BAF surcharge (from 14 SEK in December to 8 SEK in January) the total price increased only by $5 \%$. The third carrier tariff is designed differently. It consists of basic charge and bunker surcharge. In this case in 2015 the bunker surcharge has not changed significantly, while the basic fee has increased by almost $30 \%$. Although this increase remains significant, the total carriage price of the analyzed route is 
still lower than the offer of the other carriers (TT Line ferry Świnoujście-Trelleborg route was launched in January 2014 and the low price in 2014 was a form of the incentive to attract new customers).

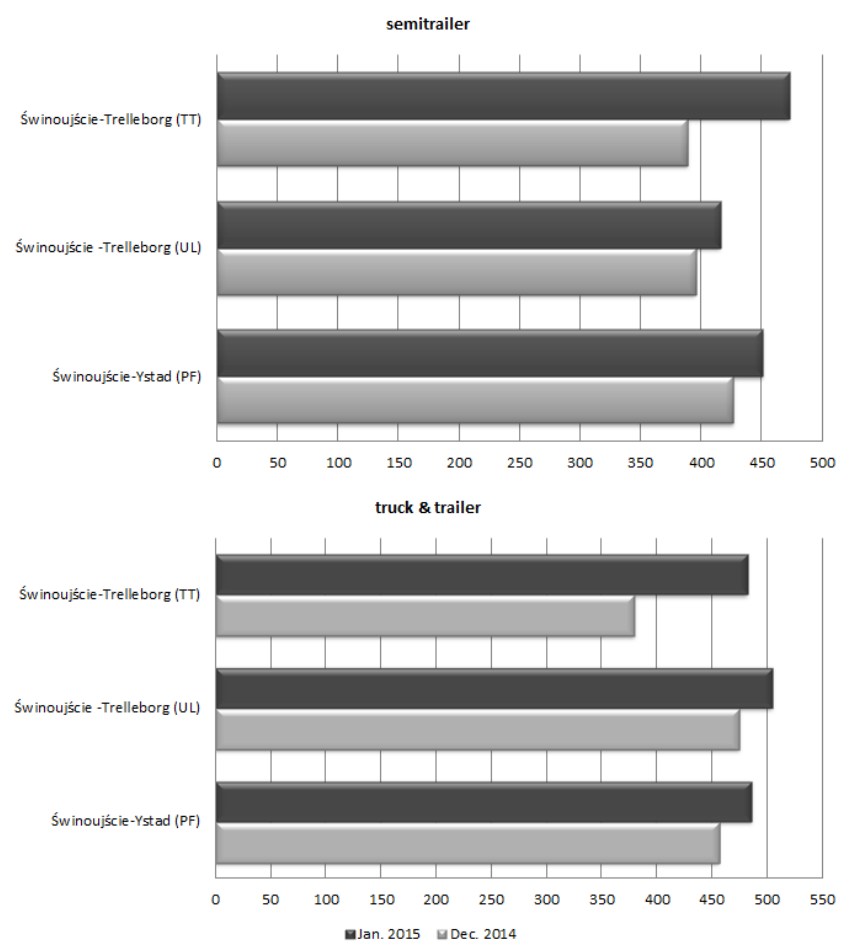

PF - Polferries; UL - Unity Line; TT - TT Line

Figure 2. Freight prices for self-propelled and non-self-propelled units on Świnoujście-Ystad/Trelleborg routes (EUR)

Source: the author's research based on: TT Line, Unity Line, Polferries ferry tariffs.

It should be emphasized, that the increase in freight was negligible due to a significant decline in maritime fuel prices. In the period between March 2014 and June 2015 the decrease of maritime fuel price was about 40\%. In February 2015 the price of low sulphur gas oil was about $600 \mathrm{USD} /$ tonne, the same as maritime oil (IFO 380) in 2014 (Fig. 3). 


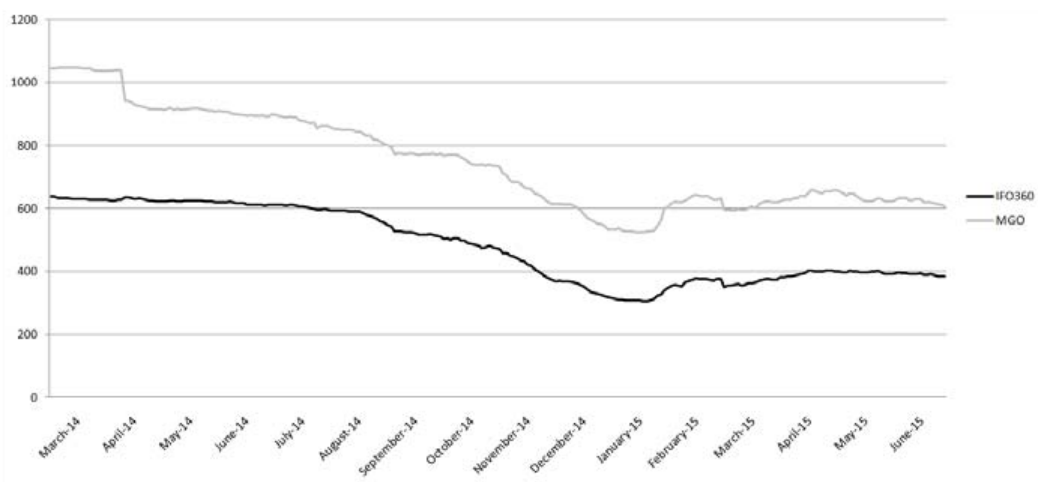

Figure 3. Average prices of: maritime diesel oil and heavy fuel oil for maritime transport in March 2014 - June 2015

Source: author's drawing based on: Bunkerworld (2015).

The modal split from sea to road is also dependent on road fuel prices. In the analyzed period of March 2014 - June 2015 road fuel prices dropped only by $15 \%$.

Considering the above, the ferry freight increases and road fuels decrease, the modal shift should appear and the ferry traffic ought to drop down. However, the opposite phenomenon has been observed. On the analyzed routes the ferry cargo volume has increased. In the first half of 2015 the growth was between $4 \%$ and $14 \%$ in comparison to the corresponding month of 2014 (Fig. 4).

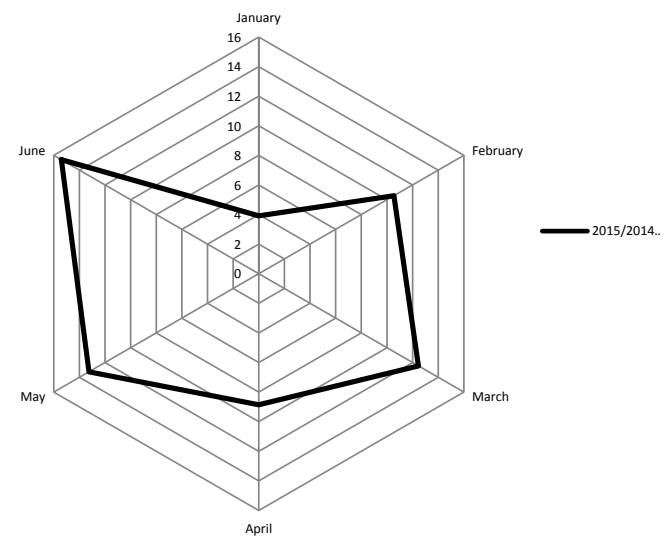

Figure 4. Dynamics of ferry traffic (lorries) on Świnoujście-Ystad/Trelleborg lines (Jan. 2015/ Dec. 2014 in \%)

Source: ferry companies statistics. 
However, it is not an unusual phenomenon. In the previous years the tightening of the sulphur rules did not lead to a decrease in ferry traffic. Figure 5 shows the dynamics of trailers transported by ferry in 2005-2013. In 2010, when the new rules in SECA were introduced, the $50 \%$ increase in ferry traffic on the Baltic Sea was observed.

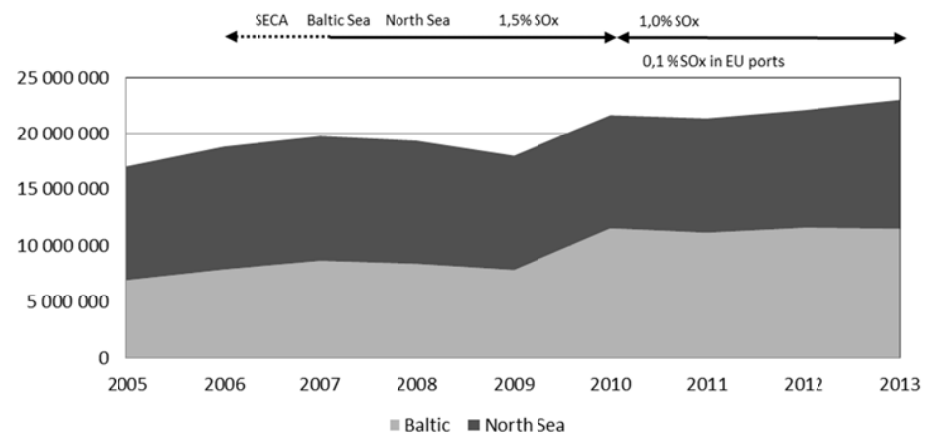

Figure 5. Ferry traffic in 2005-2013 in the North Sea and Baltic Sea (number of trailers) Source: author's drawing based on ShipPax Data.

This phenomenon can be explained by the role that ferry services play (Mańkowska 2015: 285-299). It is not true that ferry lines highly compete with the road transport. The vast majority of ferry services are mandatory and therefore non-interchangeable with any alternative road routes (eg. the shipping lines connecting islands with the mainland). The other ferry services are optional yet usually make natural extensions of land roads and significantly reduce the route distance (Kotowska 2014). So the ferry lines play rather a complementary, than substitutive, role to the road transport. Because of these features of the ferry shipping, particularly the small substitutability of ferry lines and their high correlation with road transport, the tightened rules of sulphur content in maritime fuel oil in SECA have not affected the modal shift from sea to road transport and should not affect it in the future.

\section{Summary}

Despite the increase in freight costs, the modal shift from sea to land should not be expected, simply because the majority of ferry lines cannot be replaced 
(or it is unprofitable) by road transport. This conclusion has been confirmed by the latest statistics of ferry traffic on the analyzed routes, which reveal a significant increase after the introduction of the new sulphur restrictions. However, it should be remembered that the effects of the provisions of the Sulphur Directive have been mitigated by the fall in fuel prices. Nevertheless, even if fuel prices return to the level before August 2014, the freight rates should not rise more than by $10-15 \%$ as compared to those of December 2014. In summary, the fear that the directive will affect the modal shift does not seem to be fully justified.

\section{Acknowledgements}

The project was funded by the National Science Centre allocated on the basis of the decision DEC-2012/05/B/HS4/00617.

\section{References}

Bengtsson S.K., E. Fridell, K.E. Andersson., Fuels for Short Sea Shipping: A Comparative Assessment with Focus on Environmental Impact, in: Proceedings of the Institution of Mechanical Engineers, Part M: "Journal of Engineering for the Maritime Environment" 2014, No. 228 (1).

Bonney J. Finnish Short-Sea Line Orders Two More LNG-Fueled Ships, "The Journal of Commerce", 2014, www.joc.com/maritime-news/container-lines/finnish-short-sealine-orders-two-more-lng-fueled-ships_20140925.html.

Brett D. Cost of Ocean Transport Down on Last Year Despite Sulphur Regulation, "Loading List Daily News Bulletin”, 2015, www.lloydsloadinglist.com/freight-directory/ adviceandinsight/Cost-of-ocean-transport-down-on-last-year-despite-sulphur-regulation $/ 61606$.htm?utm_source $=$ Lloyd $\% 27 \mathrm{~s}+$ Loading + List + Daily + News + Bulleti n \&utm_campaign=5537bd7dfa-Wed_30_July7_30_2014\&utm_medium=email\&utm_ term $=0 \_1$ a5c244239-5537bd7dfa-256684157\#.VNXDi0eG_X5 .

Bunkerworld 2015, http://www.bunkerworld.com/prices.

de Meyer P., F. Maes \& A. Volckaert., Emissions from International Shipping in the Belgian Part of the North Sea and the Belgian Seaports, "Atmospheric Environment", 2008, No. 42 (1).

Directive 2005/33/EC of the European Parliament and of the Council of 6 July 2005 amending Directive 1999/32/EC (OJ. L 191, 22.7.2005). 
Directive 2012/33/EU of the European Parliament and of the Council of 21 November 2012 amending Council Directive 1999/32/EC as regards the sulphur content of marine fuels 2012/33/EU Directive (OJ. L 327, 27.11.2012).

Dore A.J., M. Vieno, Y.S. Tang, U. Dragosits, A. Dosio, K.J. Weston, M.A. Sutton., Modelling the Atmospheric Transport and Deposition of Sulphur and Nitrogen over the United Kingdom and Assessment of the Influence of $\mathrm{SO}_{2}$ Emissions from International Shipping, “Atmospheric Environment” 2007, No. 41 (11).

Doudnikoff M., R. Lacoste., Effect of a Speed Reduction of Containerships in Response to Higher Energy Costs in Sulphur Emission Control Areas, in: Transportation Research Part D: "Transport and Environment" 2014 (27).

Gilbert P., From Reductionism to Systems Thinking: How the Shipping Sector Can Address Sulphur Regulation and Tackle Climate Change, "Marine Policy" 2014 (43).

Holmgren J., Z. Nikopoulou, L. Ramstedt, J. Woxenius., Modelling Modal Choice Effects of Regulation on Low-Sulphur Marine Fuels in Northern Europe, in: Transportation Research Part D: "Transport and Environment" 2014 (28).

Hongisto M., Impact of the Emissions of International Sea Traffic on Airborne Deposition to the Baltic Sea and Concentrations at the Coastline, "Oceanologia" 2014, Vol. 56, No. 2.

IMO., Report Of The Marine Environment Protection Committee On Its Fifty-Eighth Session, Marine Environment Protection Committee, 2008, MEPC 58/23/Add.1.

Kehoe J., Z. Nikopoulou, M. Liddane, L. Ramstedt, I.G. Koliousis., Impact Study of the Future Requirements of Annex VI of the MARPOL Convention on Short-Sea Shipping: Task 2 Report, "SKEMA Consolidation Study. Nautical Enterprise" (Commissioned by the European Commission), Cork, 2010.

Kotowska I., Short-Sea Shipping in the Light of the Idea of Sustainable Development of Transport (in Polish), Scientific Publishing House of the Maritime University, Szczecin 2014.

Martin F., DFDS to Invest Ł34 Million in Scrubber Technology, 2013, www.ferrynews. co.uk/news/dfds-invest-\%C2\%A334-million-scrubber-technology.

Mankowska M., The Concept of Development of Passenger Ferry Services in the Baltic Sea Region in Terms of the Growing Inter-branch Competition, in: Conference Proceedings from 17th International Conference On Transport Science, Maritime, Transport and Logistics Science, Portoroz-Slovenia, 2015.

Notteboom T., E. Delhay, K. Vanherle., Analysis of the Consequences of Low Sulphur Fuel Requirements, ITMMA-Universiteit Antwerpen Transport\&Mobility, 2010.

Panagakos G.P., E.V. Stamatopoulou, H.N. Psaraftis., The Possible Designation of the Mediterranean Sea as a SECA: A Case Study, in: Transportation Research, Part D: "Transport and Environment" 2014 (28). 
Pawłowska B., External Costs of Transport (in Polish), University of Gdańsk, Gdańsk 2010.

Polferries 2014, www.polferries.pl.

Polferries 2015, www.polferries.pl.

Roueche L., Color Line to Retrofit Exhaust Gas Scrubbers, Interferry News, 2013, www. interferry.com/node/2634.

Schembari C., F. Cavalli, E. Cuccia, J. Hjorth, G. Calzolai, N. Pérez, F. Raes., Impact of a European Directive on Ship Emissions on Air Quality in Mediterranean Harbours, "Atmospheric Environment" 2012 (61).

Shipowners under Pressure of Ecology, "Marine Observer" 2012, www.obserwator-morski.pl/artykuly/146/Armatorzy-pod-presja-ekologii.

ShipPax Data, Statistical Yearbooks of ShipPax Information (2006-2014), Halmstad, Sweden: ShipPax Information.

ShippingChina 2015, http://en.shippingchina.com.

Stena Line Introduces Methanol-Fuelled Ship, 2014, www.bairdmaritime.com/index. php?option=com_content\&view=article\&id=16255: stena-line-introduces-methanol-fuelled-ship\&catid $=96$ : cruiseferry $\&$ Itemid $=116$.

TT Line, 2014, www.ttline.com.

TT Line, 2015, www.ttline.com.

Unity Line, 2014, www.unityline.pl.

Unity Line, 2015, www.unityline.pl.

Viana M., P. Hammingh, A. Colette, X. Querol, B. Degraeuwe, I. de Vlieger, J. van Aardenne., Impact of Maritime Transport Emissions on Coastal Air Quality in Europe, "Atmospheric Environment" 2014 (90).

\section{WPLYW DYREKTYWY SIARKOWEJ NA RYNEK PROMOWY. STUDIUM PRZYPADKU POLĄCZENIA PROMOWEGO ŚWINOUJŚCIE-YSTAD/TRELLEBORG}

\section{Streszczenie}

Transport jest sektorem gospodarki, który w znacznym stopniu przyczynia się do wzrostu globalnego zanieczyszczenia. Zdecydowana większość szkodliwych substancji emitowanych w wyniku działalności transportowej pochodzi ze środków transportu 
drogowego. Jednakże za emisję tlenków siarki jest odpowiedzialny głównie transport morski.

W styczniu 2015 roku Unia Europejska na mocy dyrektywy 2012/33 / UE wprowadziła przepisy ograniczające zawartość siarki w paliwie żeglugowym, które przyczyniły się do wzrostu kosztów operacyjnych armatorów.

W artykule przedstawiono wyniki badań wpływu dyrektywy siarkowej na rynek promowy. Badania zostały oparte na analizie kosztów i wielkości przewozów ładunków na linii promowej Świnoujście-Ystad/Trelleborg w I połowie 2015 r. Przeprowadzone badania wykazały, że wprowadzenie Dyrektywy Siarkowej nie przełożyło się na obniżenie konkurencyjności połączenia promowego.

Słowa kluczowe: Dyrektywa Siarkowa, Anex VI Konwencji MARPOL, zrównoważony transport, transport morski 